\title{
Penerapan Penelitian Tindakan Kelas Cooperative Learning Tipe Peer Teaching untuk Meningkatkan Keterlibatan Siswa Dalam Pembelajaran Biologi
}

\author{
An Action Research of Assembling Cooperative Learning Type Peer \\ Teaching to Increase Student Engagement in Biology Learning
}

\author{
Nory Shenta Dewi ${ }^{1,}$, Murni Ramli ${ }^{1 *}$, Yudi Rinanto ${ }^{1}$ \\ ${ }^{1}$ Universitas Sebelas Maret, J1. Ir. Sutami 36A, Surakarta, Indonesia \\ *Corresponding author: mramlim@staff.uns.ac.id
}

\begin{abstract}
The research aims to increase students' engagement in Biology learning by applying cooperative learning method specifically peer teaching. The subjects consisted of 32 high school students focusing on Low Achievement (LA) and High Achievement (HA) students. This research is classroom action research (CAR) with 3 Cycles. The research procedure includes the stage of reflection, planning, implementation of action and observation. Behavioral Engagement (BE) data obtained through observation, other data in the form of Psychological Engagement (PE) and Cognitive Engagement (CE) obtained through student engagement questionnaire based on Student Engagement Instrument (SEI). Technique of data validation used is triangulation technique. Technique of analysis data performed by data reduction, data presentation and drawing conclusions based on qualitative descriptive analysis. The results showed that cooperative learning method specifically peer teaching can increase student engagement in biology learning. The average percentage of all BE aspects observed in LA students before the treatment given, Cycle I, Cycle II and Cycle III respectively was $13.72 \% ; 35.24 \% ; 48.26 \%$ and $64.24 \%$ respectively. Meanwhile BE results of HA students before the treatment given, Cycle I, Cycle II and Cycle III respectively were 22.22\%; 48.97\%; 56.6\% and 64.76\% respectively. The results of PE of LA students before the treatment given to Cycle III increased by $3.54 \%$ while PE in HA students before the treatment given to Cycle III increased from $3.75 \%$. The result of CE analysis of LA students has increased before the treatment given toward Cycle III that is $2.94 \%$ while in HA students increased by $2.95 \%$.
\end{abstract}

Keywords: Classroom Action Research (CAR), Cooperative Learning, Peer Teaching, Student Engagement, Biology

\section{PENDAHULUAN}

Pembelajaran yang baik melibatkan peran aktif siswa di dalamnya. Pembelajaran aktif merupakan suatu metode yang melibatkan siswa di dalam proses pembelajaran. Pembelajaran ini mengharuskan siswa untuk dapat melakukan pembelajaran yang berarti (meaningful learning) dan memikirkan apa yang sedang mereka kerjakan ketika belajar (Prince, 2004).

Unsur inti pembelajaran aktif adalah aktivitas siswa dan keterlibatan dalam proses pembelajaran (Prince, 2004). Keterlibatan terdiri dari sikap, pemikiran, dan perilaku individu serta komunikasi dengan orang lain. Keterlibatan siswa adalah siswa yang meluangkan waktu, energi, pemikiran, usaha, dan, sampai tingkat tertentu mencurahkan perasaannya ke dalam pembelajaran mereka (Dixson, 2015).
Keterlibatan siswa merupakan hal yang penting untuk diwujudkan di dalam proses pembelajaran. Hal ini dikarenakan tujuan utama pembelajaran di kelas adalah untuk membuat siswa terlibat secara intelektual pada materi pembelajaran. Siswa diharapkan aktif secara intelektual daripada hanya pasif menerima informasi, baik dari guru maupun buku teks dan tidak menggunakan pemikirannya dalam belajar (Edwards, 2015). Keterlibatan siswa juga merupakan kunci untuk menjaga siswa agar dapat terhubung dengan pembelajaran yang sedang dilakukan (Dixson, 2015). Ketika siswa ikut serta di dalam memperoleh pengetahunnya, maka siswa dapat memulai proses kontruksi pengetahuan (Velez, 2011). Keterlibatan siswa juga merupakan prediktor pembelajaran dan prestasi belajar, retensi dan kelulusan dari sekolah menengah atas dan masuk perguruan tinggi. Keterlibatan merupakan faktor yang menjaga siswa dari perilaku beresiko di masa remaja seperti 
membolos, keterlibatan dalam geng, kenakalan remaja dan perilaku seksual beresiko (Furrer, Skinner, \& Pitzer, 2014).

SMA Negeri 2 Surakarta memiliki siswa dengan prestasi yang bervariasi. Setiap siswa memiliki peran serta yang berbeda-beda di dalam mengikuti proses pembelajaran. SMA Negeri 2 Surakarta memiliki 4 kelas IPA untuk kelas X. Biologi merupakan mata pelajaran yang wajib dipelajari untuk jurusan IPA, dan terdiri dari dua kali pertemuan. Pertemuan pertama selama 1x45 menit, sedangkan pertemuan kedua selama $2 \times 45$ menit.

Observasi dilakukan di SMA X Surakarta yang beralamat di Jalan Monginsidi No.40, Gilingan, Banjarsari, Kota Surakarta pada kelas X MIPA 3. Kelas X MIPA 3 adalah salah satu kelas yang memiliki jumah siswa sebanyak 32 siswa, terdiri dari 14 laki-laki dan 18 perempuan. Posisi duduk para siswa tidak tetap karena kelas menerapkan sistem rolling mengular setiap minggu.

Berdasarkan hasil pengamatan selama magang kependidikan III, keterlibatan siswa di dalam mengikuti pembelajaran masih sangat kurang. Kondisi kelas saat peneliti mengajar terlihat pasif. Banyak siswa pada kelas yang diampu peneliti saat magang tidak memperhatikan penjelasan guru dan mengobrol dengan teman mengenai hal yang tidak ada kaitannya dengan biologi.

Siswa kurang aktif bertanya ketika menemui kesulitan dan apabila ditunjuk untuk menjawab pertanyaan siswa tidak mau menjawab karena takut jawaban yang diungkapkan salah. Beberapa siswa lebih banyak mengobrol sendiri dengan teman, membuka media sosial di handphone, memainkan game online dan mengantuk ketika pembelajaran berlangsung. Terdapat beberapa anak yang selalu memperhatikan dan mengikuti instruksi dari guru namun ada juga yang selalu menganggu temannya ketika belajar, membuat keributan dan selalu ingin diperhatikan oleh guru.

Hasil belajar siswa kelas X MIPA sangat rendah. KKM mata pelajaran Biologi kelas X adalah 70. Dari 32 orang siswa di dalam kelas hanya ada $12,5 \%$ siswa yang memperoleh nilai di atas KKM ketika Penilaian Harian Bersama (PHB). Hal yang sama juga terjadi ketika ulangan harian Bakteri. Terdapat 56,25\% siswa yang lulus KKM sedangkan $43,75 \%$ siswa mendapatkan nilai di bawah KKM.

Pendekatan yang telah dilakukan oleh peneliti untuk meningkatkan keterlibatan siswa diantaranya adalah dengan cara menerapkan pembelajaran kontekstual dan pembelajaran berbasis diskusi di dalam kelompok. Peneliti membagi siswa ke dalam kelompok berdasarkan tingkat intelegensi untuk kemudian mendiskusikan suatu topik yang ada di dalam Lembar Kerja Siswa (LKS). Hasil diskusi kemudian dipresentasikan di depan kelas. Pembelajaran kontekstual dilakukan dengan cara membawa beberapa contoh nyata terkait pembelajaran yang sedang berlangsung (contoh: yoghurt dan nata de coco ketika mempelajari materi bakteri) serta menayangkan video dan gambar-gambar terkait materi pembelajaran. Peneliti juga menerapkan pembelajaran dengan media poster yang dibuat sendiri oleh siswa di dalam kelompok.

Berbagai pendekatan yang dilakukan mampu meningkatkan keterlibatan aktif siswa di dalam pembelajaran. Siswa mulai antusias ketika pembelajaran berlangsung. Akan tetapi hal ini hanya memperbaiki sebagian siswa saja. Siswa yang memiliki prestasi belajar rendah dan sering menganggu teman tetap tidak berubah. Siswa masih harus ditunjuk untuk mengungkapkan pendapatnya.

Berdasarkan deskripsi permasalahan di atas, maka diperlukan suatu perubahan di dalam pembelajaran. Diperlukan suatu metode untuk menjadikan siswa mampu terlibat secara aktif di dalam pembelajaran. Pembelajaran yang berpusat pada siswa (student-centered) dan cooperative learning merupakan solusi yang dapat diterapkan untuk meningkatkan keterlibatan siswa di dalam pembelajaran (Herrmann, 2013).

Johnson dan Johnson (1998) dalam Huda (2013) mendefinisikan cooperative learning sebagai pembelajaran yang memungkinkan siswa saling bekerja sama untuk mencapai tujuan bersama. Cooperative learning dilakukan dengan cara membentuk kelompok-kelompok kecil yang di dalamnya setiap siswa saling bekerjasama untuk meningkatkan pembelajaran. Setiap anggota berusaha mencapai suatu tujuan yang nantinya dapat dirasakan oleh setiap anggota.

Berbagai penelitian menyatakan bahwa terdapat hubungan positif antara cooperative learning dengan keterlibatan siswa. Zhao \& Kuh (2004) dalam penelitiannya menyatakan bahwa komunitas belajar yang menggabungkan pembelajaran aktif dan kolaboratif memberikan pengaruh positif terhadap keterlibatan pesertanya. Sejalan dengan penelitian yang dilakukan oleh Herrmann (2013) bahwa cooperative learning yang diterapkan di dalam tutorial dapat meningkatkan partisipasi siswa di kelas.

Salah satu cooperative learning yang dapat meningkatkan keterlibatan siswa adalah peer teaching. Peer teaching dapat mendorong siswa untuk berperan aktif dalam memperoleh pengetahuannya (Velez, 2011). Pembelajaran ini dalam bentuknya yang paling sederhana didefinisikan sebagai suatu proses pemberian bantuan dari sesama siswa untuk mendapatkan pengetahuan, pemahaman maupun ketrampilan yang dapat menguntungkan kedua belah pihak (Williams \& Fowler, 2014).

Berdasarkan hasil penelitian, dapat diketahi bahwa siswa lebih menikmati pembelajaran dan terlibat secara aktif di dalam pembelajaran dengan teman sebaya dibandingkan dengan pembelajaran yang berpusat pada guru. Peer teaching adalah cara yang efektif untuk meningkatkan keterlibatan dan partisipasi siswa. Pembelajaran ini juga memfasilitasi lingkungan kelas yang hangat dan interaktif (Velez, 2011). Pembelajaran berbasis peer teaching yang diterapkan untuk mahasiswa juga mampu meningkatkan prestasi akademiknya jika dibandingkan dengan mahasiswa yang tidak mengikutinya (Williams \& Fowler, 2014). 
Penelitian yang cocok digunakan untuk memperbaiki keterlibatan siswa di kelas adalah Penelitian Tindakan Kelas. Penelitian Tindakan Kelas (PTK) merupakan sebuah proses untuk memperbaiki pembelajaran dengan cara memasukkan perubahan yang melibatkan pendidik untuk memperbaiki pengajaran yang dilakukan (Mertler, 2009 dalam Ary, Jacobs, Sorensen, \& Razavieh, 2010). Penelitian tindakan kelas dapat digunakan untuk mendorong guru merefleksikan pengajaran mereka sendiri untuk meningkatkan kualitas dirinya sendiri dan juga peserta didik yang diajar (Schmidt, 2002).

Berdasarkan latar belakang masalah di atas, rumusan masalah pada penelitian ini adalah "Apakah PTK cooperative learning tipe peer teaching dapat meningkatkan keterlibatan siswa dalam pembelajaran?".

\section{METODE PENELITIAN}

Penelitian dilaksanakan di kelas X MIPA 3 SMA N 2 Surakarta. Pendekatan pada penelitian ini adalah collaborative action research. Subjek penelitian ini adalah siswa kelas Kelas X MIPA 3 tahun pelajaran 2017/2018 yang memiliki jumah siswa sebanyak 32 , terdiri dari 14 siswa dan 18 siswi. Penelitian ini berfokus pada siswa High Achievement (HA) dan Low Achievement (LA). Pembagian ini dilakukan berdasarkan nilai kognitif siswa. Siswa HA yang dijadikan subjek penelitian merupakan siswa yang nilai kognitifnya tinggi di dalam kelas, sedangkan siswa LA adalah siswa dengan nilai kognitif sangat rendah di dalam kelas.

Penelitian merupakan Penelitian Tindakan Kelas (PTK) dengan 3 Siklus. Prosedur penelitian meliputi tahap: refleksi, perencanaan, pelaksanaan tindakan dan pengamatan. Data berupa keterlibatan peserta didik di dalam kelas. Pengumpulan data dilakukan dengan angket, observasi, dan dokumentasi untuk mengetahui keterlibatan peserta didik. Data berupa Behavioral Engagement (BE) yang diperoleh melalui observasi, data lain berupa Psychological Engagement (PE) dan Cognitive Engagement (CE) yang diperoleh melalui angket keterlibatan siswa berdasarkan Student Engagement Instrument (SEI). Validasi data menggunakan teknik triangulasi. Teknik analisis data dilakukan dengan reduksi data, penyajian data dan penarikan kesimpulan berdasarkan analisis deskriptif kualitatif.

\section{HASIL DAN PEMBAHASAN}

Pengamatan dan pencatatan aktivitas siswa dilakukan melalui observasi pembelajaran. Aktivitas siswa yang diamati meliputi aktivitas berbicara dengan guru, berbicara dengan siswa, berbicara dengan kelompok, mendengarkan penjelasan guru, mendengarkan siswa, mendengarkan kelompok, kegiatan menulis dan membaca. Aktivitas yang dicatat adalah aktivitas yang berkaitan dengan pembelajaran, pada tahap ini juga dibagikan angket keterlibatan siswa berdasarkan Student Engagement Instrument (SEI) (Grier-reed, Appleton, Rodriguez, Ganuza, \& Reschly, 2012).
Gambar 1 menunjukkan perbandingan BE siswa HA dan LA pada Pratindakan, Siklus I, Siklus II dan Siklus III. Siswa HA menunjukkan angka 22,22\% pada pratindakan kemudian mengalami kenaikan menjadi $44,97 \%$ pada Siklus I. Pada siklus II kembali mengalami kenaikan menjadi $56,60 \%$ dan pada Siklus III naik menjadi $64,76 \%$. Siswa LA pada tahap pratindakan ada di angka $13,72 \%$, naik menjadi $35,24 \%$ pada Siklus I. siklus II Siswa LA kembali naik dengan angka 48,26\% dan pada Siklus III naik menjadi $64,24 \%$.

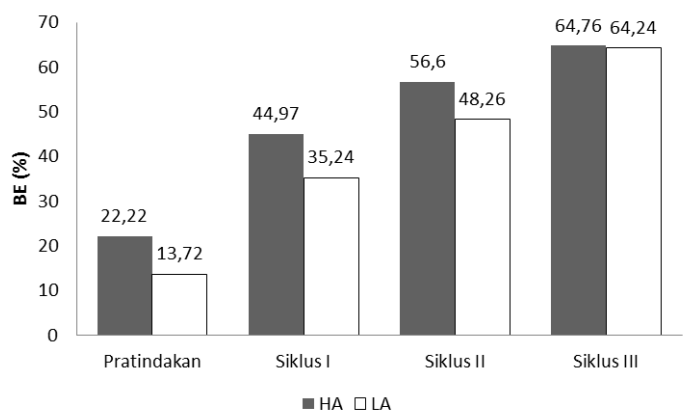

Gambar 1. Perbandingan Behavioral Engagement (BE) pada Pratindakan, Siklus I, Siklus II dan Siklus III

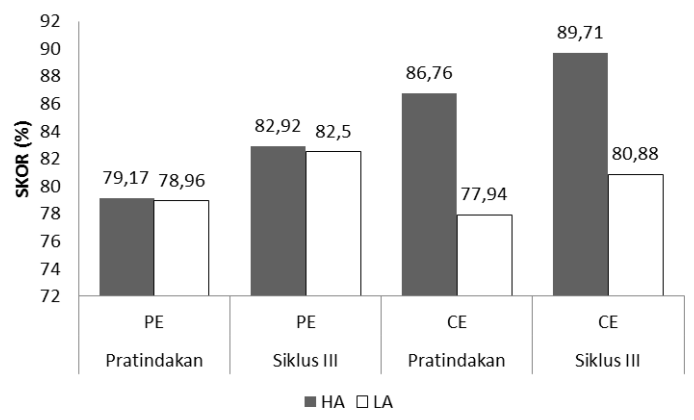

Gambar 2. Perbandingan Psychological Engagement (PE) dan Cognitive Engagement (CE) pada Pratindakan dan Siklus III

Perbandingan PE dan CE pada pratindakan dan Siklus III siswa HA dan LA disajikan pada Gambar 2. Kedua aspek menunjukkan kriteria "sangat setuju" baik pada siswa HA maupun LA, namun dengan perolehan angka yang berbeda. PE siswa HA dan LA memperoleh angka yang hampir sama pada tahap pratindakan yaitu $79,17 \%$ dan $78,96 \%$. Pada Siklus III PE siswa HA dan LA mengalami peningkatan menjadi $82,92 \%$ dan $82,5 \%$.

CE siswa HA pada Pratindakan ada pada angka $87,76 \%$ kemudian meningkat menjadi $89,71 \%$ di Siklus III. Siswa LA memperoleh skor CE lebih rendah apabila dibandingkan dengan siswa HA. CE siswa LA pada Pratindakan berada pada agka 77,94\% dan meningkat menjadi $80,88 \%$ pada Siklus III.

Berdasarkan data observasi Pratindakan pada kelas X MIPA 3 SMA Negeri 2 Surakarta menunjukkan rendahnya keterlibatan siswa (student engagement) di dalam mengikuti pembelajaran Biologi. Indikasi rendahnya keterlibatan siswa 
diketahui berdasarkan hasil observasi Behavioral Engagement (BE) selama proses pembelajaran.

Rendahnya BE siswa disebabkan oleh pembelajaran di dalam kelas yang belum memfasilitasi siswa untuk terlibat aktif di dalamnya. Pembelajaran belum memberi kesempatan kepada siswa untuk bekerja di dalam kelompok dan saling bertukar informasi satu sama lain. Kegiatan belajar yang terjadi hanya sebatas mendengarkan guru menjelaskan melalui slide PPT. Pembelajaran yang berpusat pada guru bersifat tidak kontekstual. Fokus pembelajaran adalah pada konten, bukan pada proses pembelajaran. Hal ini menyebabkan siswa berperan secara pasif karena pengetahuan ditransfer langsung dari guru kepada siswa dan tugas-tugas diberikan secara individual (Smit, Brabander, \& Martens, 2014).

Upaya untuk memperbaiki keterlibatan siswa dalam pembelajaran dilakukan dengan penerapan cooperative learning tipe peer teaching menunjukkan perubahan yang positif pada setiap siklus. Perubahan positif ditunjukkan dengan adanya peningkatan ratarata frekuensi aktivitas siswa pada seluruh aspek yang diamati dalam Behavioral Engagement (BE). Adanya perubahan positif juga ditemukan pada Psychological Engagement (PE) dan Cognitive Engagement (CE) berdasarkan angket SEI (Student Engagement Instrumen) yang diberikan pada tahap Pratindakan dan Siklus III.

Pembelajaran dengan cooperative learning tipe peer teaching pada Siklus I telah meningkatkan keterlibatan siswa apabila dibandingkan dengan keterlibatan siswa pada tahap Pratindakan. Berdasarkan hasil pengamatan selama proses peer teaching yang dilakukan ketika berdiskusi terdapat siswa HA yang belum terbiasa untuk memberikan tutorship kepada temannya. Seperti yang terjadi pada pasangan siswa No. 28 (HA) dan No.31 (LA), siswa No.28 terlihat mengerjakan LKS sendiri dan tidak memberikan pengajaran kepada siswa No.31. Permasalahan ini tentu berdampak pada frekuensi aspek berbicara dengan kelompok dan mendengarkan kelompok siswa No.31 lebih rendah jika dibandingkan dengan siswa LA pada kelompok lain. Desain pengelompokan yang berjumlah dua orang cukup efektif untuk menghindari siswa tidak bekerja di dalam kelompok ketika mengerjakan tugas dari guru. Siswa dapat fokus selama pembelajaran dan tidak melakukan kegiatan lain yang tidak penting seperti membuka media sosial dan mengobrol hal lain di luar pembelajaran. Selain itu siswa juga dapat memanfaatkan gadget dengan baik, yaitu untuk mencari sumber informasi di internet. Siswa HA maupun LA banyak bertanya kepada guru apabila menemukan sesuatu yang tidak dimengerti.

Hasil pelaksanaan Siklus II secara umum menunjukkan peningkatan seluruh aspek BE. Siswa HA lebih mempersiapkan diri ketika pembelajaran dan lebih terbiasa untuk memberikan tutorship kepada siswa LA. Aspek berbicara dengan kelompok dan mendengarkan kelompok siswa HA dan siswa LA memperoleh angka peningkatan paling tinggi dibandingkan aspek yang lainnya. Terdapat beberapa perubahan anggota kelompok pada siklus II. Siswa
No.28 duduk dengan siswa No.12, sedangkan siswa No.23 duduk dengan siswa No.31.

Pelaksanaan tindakan Siklus III menunjukkan perubahan positif pada seluruh aspek BE. Pada Siklus III pencapaian BE siswa HA dan LA memperoleh hasil yang mirip. Pengelompokan pada Siklus III dilakukan dengan komposisi dua siswa HA dan dua siswa LA. Susunan pengelompokan ini dilakukan karena pelaksanaan praktikum pada Siklus III. Setiap kelompok praktikum melakukan percobaan dengan variabel bebas yang berbeda-beda. Setiap siswa terlihat antusias dan memiliki rasa ingin tahu yang tinggi.

Pembelajaran peer teaching dapat mendorong siswa untuk terlibat aktif di dalam pembelajaran. Hasil pengamatan menunjukkan perbedaan yang cukup mencolok pada BE pratindakan yang menggunakan metode ceramah dengan hasil tindakan Siklus I, Siklus II dan Siklus III. Hasil ini sejalan dengan Velez (2011) dalam penelitiannya bahwa siswa lebih menikmati pembelajaran dan terlibat secara aktif di dalam pembelajaran dengan teman sebaya dibandingkan dengan pembelajaran yang berpusat pada guru. Peer teaching adalah cara yang efektif untuk meningkatkan keterlibatan dan partisipasi siswa.

Peningkatan BE siswa LA cenderung lebih tinggi jika dibandingkan dengan siswa HA. Kondisi ini disebabkan karena siswa LA menjadi lebih bersemangat, termotivasi dan memiliki rasa senang untuk belajar. Pembelajaran dengan bantuan teman sebaya memfasilitasi lingkungan kelas yang hangat dan interaktif (Pusporini, 2011). Hafiz \& Wisdiarman, (2014) menyatakan bahwa tutor sebaya menyebabkan siswa terpacu semangatnya untuk mempelajari materi ajar dengan baik. Kondisi ini membuat siswa menjadi aktif dan terlibat dalam pembelajaran. Siswa merasa lebih dekat dengan teman sebaya daripada dengan guru sehingga aktivitas siswa LA menjadi lebih tinggi dari sebelumnya.

\section{Behavioral Engagement (BE)}

BE yang diamati pada penelitian ini meliputi beberapa aspek, yaitu berbicara (berbicara dengan guru, berbicara dengan siswa lain di luar kelompok, berbicara dengan kelompok); mendengarkan (mendengarkan guru, mendengarkan siswa lain di luar kelompok, mendengarkan kelompok), membaca dan menulis. Data BE yang diperoleh merupakan hasil observasi di dalam kelas selama proses pembelajaran berlangsung dengan cara menghitung frekuensi setiap aktivitas pada setiap siklus.

Aspek berbicara dalam penelitian ini meliputi berbicara dengan guru, berbicara dengan siswa lain di luar kelompok, dan berbicara dengan kelompok. Aktivitas berbicara yang diamati dapat berupa siswa yang saling berdiskusi dan bertanya mengenai hal-hal yang ada kaitannya dengan materi pembelajaran dan proses pembelajaran.

Berdasarkan hasil pengamatan aktivitas berbicara siswa pada Siklus I, Siklus II dan Siklus III, terjadi peningkatan pada aspek berbicara dengan guru, berbicara dengan siswa lain di luar kelompok, dan 
berbicara dengan kelompok baik pada siswa HA maupun LA. Peningkatan aspek berbicara pada siswa HA dikarenakan tugasnya untuk memberikan tutorship kepada siswa LA yang sekelompok. Aktivitas mengerjakan tugas dari guru yang diberikan secara berkelompok memancing rasa ingin tahu siswa, siswa berusaha bertanya kepada teman dan guru mengenai hal-hal yang tidak diketahui. Siswa LA tidak sungkan untuk bertanya pada siswa HA.

Strategi pembelajaran peer teaching adalah suatu proses pemberian bantuan dari sesama siswa untuk mendapatkan pengetahuan, pemahaman maupun ketrampilan yang dapat menguntungkan kedua belah pihak. (Williams \& Fowler, 2014). Siswa yang terlibat dengan siswa lain yang memiliki kemampuan akademis lebih tinggi akan dapat melakukan proses ko-konstruksi pengetahuan. Ko-konstruksi pengetahuan adalah suatu proses sosial, yaitu orang saling berinteraksi (biasanya secara lisan) untuk memahami dan memecahkan masalah. Melalui proses ini, siswa dapat memperoleh ketrampilan dan keyakinan untuk menguasai konsep (Velez, 2011).

Peningkatan aktivitas berbicara siswa dapat diasumsikan sebagai akibat dari pengelompokan siswa HA dengan LA dan perlakuan peer teaching yang diberikan. Siswa HA memberikan sumbangan kepada siswa LA selama proses peer teaching mengakibatkan kenaikan frekuensi aktivitas berbicara siswa LA, terutama pada aspek berbicara dengan kelompok.

Aktivitas berbicara siswa LA yang meningkat dapat disebabkan karena siswa merasa lebih nyaman dan leluasa untuk bertanya dan mengungkapkan pendapatnya dengan temannya sendiri. Pusporini (2011) dalam penelitiannya menyatakan bahwa siswa cenderung merasa takut dan tidak berani untuk bertanya atau mengeluarkan pendapatnya kepada guru, tetapi siswa akan lebih suka dan berani bertanya atau mengeluarkan pendapatnya tentang materi pelajaran kepada temannya atau siswa lain. Pernyataan ini juga sejalan dengan Hafiz \& Wisdiarman, (2014) bahwa tutor sebaya dapat membuat siswa menjadi lebih mudah dan leluasa dalam menyampaikan masalah yang dihadapi sehingga siswa yang bersangkutan lebih bersemangat untuk mempelajari materi ajar. Disamping itu dengan adanya tutor sebaya siswa yang kurang aktif menjadi aktif karena tidak malu lagi untuk bertanya dan mengeluarkan pendapat secara bebas.

Aspek mendengarkan dalam penelitian ini meliputi mendengarkan guru, mendengarkan siswa lain di luar kelompok, mendengarkan kelompok. Aktivitas mendengarkan yang diamati dapat berupa siswa yang saling berdiskusi dan mendengarkan pendapat siswa mengenai materi pelajaran yang sedang menjadi bahan diskusi. Siswa HA yang berperan sebagai guru memberikan penjelasan yang didengarkan siswa LA yang berperan sebagai murid.

Hasil observasi menunjukkan peningkatan keseluruhan aspek mendengarkan dari tahap pratindakan menuju Siklus I, Siklus II dan Siklus III. Peningkatan aspek mendengarkan disebabkan oleh interaksi yang terjadi antara siswa HA dan LA.
Peningkatan aktivitas mendengarkan siswa LA diasumsikan sebagai sumbangan yang diberikan dari siswa HA. Siswa HA memberikan bantuan kepada siswa LA dalam belajar, hal ini membuat siswa lebih sering bertanya kepada teman dan guru, sehingga aktivitas mendengarkannya juga meningkat. Maria (2012) menyatakan bahwa tutor sebaya (peer teaching) merupakan suatu proses pemberian bantuan kepada siswa. Peserta didik yang lebih mampu menyelesaikan pekerjaannya sendiri membantu peserta didik lain yang kurang mampu dalam menyelesaikan pekerjaannya. Peer teaching merupakan pendekatan kooperatif bukan kompetitif. Rasa saling menghargai dan mengerti dibina diantara peserta didik yang bekerja sama.

Jika dilihat dari rata-rata aspek mendengarkan, maka keseluruhan siswa mengalami perubahan positif. Namun pada beberapa siswa mengalami kondisi tetap dan penurunan pada aspek ini. Hasil pengamatan pada siklus I, siswa No.12 tidak mengalami peningkatan pada aspek mendengarkan siswa lain, sedangkan siswa No.5 mengalami penurunan sebesar $8,33 \%$. Hal ini dapat disebabkan karena siswa telah dibagi menjadi kelompokkelompok kecil dan mendiskusikan permasalahan yang diberikan guru dengan kelompoknya masingmasing sehingga mengurangi intensitasnya untuk mendengarkan pendapat siswa dari luar kelompoknya sendiri. Pada Siklus II siswa No.28 dan No.23 tidak mengalami perubahan pada aspek mendengarkan guru. Penurunan pada aspek mendengarkan guru juga terjadi pada Siklus II, yaitu pada siswa No.29. Penyebab dari masalah ini dapat dikarenakan pembelajaran yang terjadi lebih berpusat pada siswa. Guru hanya sebagai fasilitator, sehingga peran siswa lain baik di dalam maupun di luar kelompok yang lebih besar. Pembelajaran peer teaching dapat melatih siswa untuk melakukan proses belajar secara mandiri. Siswa lebih banyak terlibat dalam proses pembelajaran (student centred) (Usman, 2017). Peer teaching merupakan salah satu pembelajaran aktif. Peranan guru dalam pembelajaran aktif adalah sebagai sebagai fasilitator, yaitu membantu siswa untuk belajar (Warsono \& Hariyanto, 2014).

Pembelajaran dengan memanfaatkan tutor sebaya dapat membantu rekan sebaya dalam aspek akademis, emosi disiplin. Dengan bantuan tutor sebaya pembelajaran akan lebih efektif, komunikatif dan efisien karena bahasa tutor lebih mudah dipahami. Dengan bantuan tutor sebaya ini peserta didik dijadikan sebagai subjek pembelajaran yaitu peserta didik yang diajak untuk dijadikan tutor atau sumber belajar dan tempat bertanya bagi teman ssebayanya. Bahasa yang digunakan mudah dipahami dan hubungan interpersonal antara teman sebaya terjalin dengan baik, sehingga terjadi komunikasi pembelajaran yang efektif, aktif, inovatif dan komunikatif (San, Putu, \& Manik, 2013).

Aspek membaca mengalami perubahan positif dari siklus I menuju Siklus III. Pada Siklus I siswa No.31 (LA) tidak mengalami peningkatan pada aspek membaca, namun dapat meningkat pada siklus selanjutnya. Demikian juga pada Siklus III siswa No.3 
(HA), No.28 (HA) dan No.29 (LA) tidak mengalami peningkatan. Pemberian Lembar Kerja Siswa (LKS) yang diikerjakan di dalam kelompok secara tidak langsung memaksa siswa untuk mencari berbagai sumber informasi guna melengkapi LKS. Siswa dapat memanfaatkan gadget dengan baik untuk mencari sumber informasi di internet. Pembelajaran yang diterapkan bersifat student centered sehingga siswa harus secara mandiri mencari sumber informasi yang dibutuhkan untuk dapat memecahkan masalah (Usman, 2017). Pembelajaran yang berpusat pada siswa telah terbukti membawa siswa ke tingkat pemikiran kritis yang lebih tinggi, pemecahan masalah, dan peningkatan sikap untuk belajar(Overby, 2011).

Aktivitas menulis juga mengalami peningkatan pada setiap siklus. Aktivitas menulis yang diamati adalah menulis di LKS, menulis di buku catatan dan papan tulis. Peningkatan aktivitas menulis pada siswa LA disebabkan karena pada tahap pratindakan siswa LA tidak mau mencatat penjelasan yang diberikan oleh guru sedangkan pada Siklus I siswa dituntut untuk menulis hasil diskusi di dalam LKS. Siswa No.3 (HA) tidak mengalami peningkatan aspek ini pada Siklus I. Pada siklus II terjadi penurunan pada beberapa siswa LA dalam aspek menulis yaitu siswa No.12 (LA) dan siswa No.5 (LA). Siswa No. 32 (HA) dan No.25 (HA) tidak mengalami peningkatan. Tidak meningkatnya aspek ini juga terjadi pada Siklus III yaitu pada siswa No. 1 (HA), No.23(HA) dan No.28 (HA). Hal ini terkait dengan peran siswa LA yang lebih banyak menulis hasil diskusi dibandingkan dengan siswa HA. Kegiatan menulis siswa LA meningkat karena siswa dibimbing untuk menemukan konsep-konsep baru di dalam pembelajaran melalui tutorship yang diberikan siswa HA serta LKS yang diberikan guru. Kegiatan menulis dilakukan siswa untuk membantunya ketika memperoleh pengetahuan baru yaitu untuk membantu memperjelas dan menghubungkan ide-ide ilmiah (Balgopal \& Wallace, 2009). Siswa HA menerangkan dan memberikan pemecahan masalah sementara siswa LA mendengarkan dan menuliskan jawaban.

\section{Psychological Engagement (PE) dan Cognitive Engagement (CE)}

PE dan CE dianalisis berdasarkan angket SEI (Grier-reed et al., 2012) yang diisi oleh siswa pada tahap Pratindakan dan Siklus III. PE terdiri dari tiga indikator, yaitu hubungan guru dan siswa, dukungan teman dalam pembelajaran dan dukungan keluarga dalam pembelajaran. Terjadi peningkatan PE dari tahap Pratindakan menuju Siklus III, baik pada siswa HA maupun LA. Hasil analisis angket menunjukkan kemiripan hasil PE pada siswa HA dan LA yang dapat dilihat pada Gambar 2. Kemiripan hasil ini menunjukkan bahwa PE siswa HA dan LA hampir sama. Hal ini dimungkinkan karena siswa LA dan HA berada dalam satu kelas yang sama sehingga temanteman yang ada di sekelilingnya sama dan guru yang mengajar juga sama. Baik siswa LA maupun HA memiliki perasaan dan hubungan yang sama dengan teman sekelas dan guru. Keterlibatan emosi siswa pada sekolah menunjukkan minat, nilai, dan emosi terhadap sekolah, misalnya: perasaan di kelas, perasaan terhadap sekolah dan guru, perasaan terhadap perlakuan, disiplin dan motivasi, perasaan memiliki, perasaan positif, dan menghargai prestasi akademik di sekolah. Keterlibatan siswa pada sekolah merupakan mediator bagi peran kompetensi emosi terhadap prestasi akademik. Semakin tinggi kompetensi emosi siswa, semakin tinggi keterlibatan siswa pada aktivitas akademik sekolah (Dharmayana, 2012).

Selama proses pembelajaran siswa terlihat lebih bersemangat dan termotivasi untuk belajar apabila dibandingkan saat tahap pratindakan. Susana belajar menjadi lebih hidup karena siswa aktif bekerja di dalam kelompok dan bertanya, baik kepada siswa maupun guru. Dengan pembelajaran peer teaching dapat meningkatkan dukungan teman dalam pembelajaran. Hasil ini sesuai dengan Velez (2011) bahwa siswa lebih menikmati dan terlibat aktif dalam pembelajaran dengan teman sebaya dibandingkan dengan pembelajaran yang berpusat pada guru. Interaksi positif antara guru dan siswa akan mendukung kebutuhan sosial, emosional dan kognitif siswa. Melalui interaksi yang baik antara guru dengan siswa dapat meningkatkan minat belajar dan kesempatan belajar. Hal ini dikarenakan kesempatan belajar yang diberikan oleh guru lebih besar. Guru memberikan dukungan kepada siswa untuk berpartisipasi secara aktif di dalam pembelajaran (Gregory, Allen, \& Mikami, 2014). Peer teaching adalah cara yang efektif untuk meningkatkan keterlibatan dan partisipasi siswa, memfasilitasi lingkungan kelas yang hangat dan interaktif. Pembelajaran ini dalam bentuknya yang paling sederhana didefinisikan sebagai suatu proses pemberian bantuan dari sesama siswa untuk mendapatkan pengetahuan, pemahaman maupun ketrampilan yang dapat menguntungkan kedua belah pihak (Williams \& Fowler, 2014).

CE terdiri dari tiga indikator, yaitu kontrol dan relevansi kerja sekolah, harapan dan tujuan masa depan serta motivasi dari luar peserta didik. CE dapat mengukur sejauh mana siswa berupaya dalam mengerjakan tugas-tugas sekolah yang dihadapi (Mandernach, 2015). CE mengalami peningkatan dari tahap pratindakan menuju Siklus III. Peningkatan terjadi pada siswa HA maupun LA. Hasil menunjukkan CE siswa HA lebih tinggi daripada CE siswa LA (Gambar 4.13). Perbedaan ini dimungkinkan karena siswa HA memiliki kemampuan kognitif dan BE yang lebih tinggi daripada siswa LA. Siswa yang berprestasi akademik tinggi cenderung memiliki motivasi daya saing yang kuat dibanding dengan siswa yang berprestasi rendah (Latipah, 2010). Keterlibatan secara emosi juga memberikan pengaruh terhadap keterlibatan kognitif siswa. Kompetensi emosi memperkuat berkembangnya sikap dan perilaku bersekolah yang positif. Sikap dan perilaku bersekolah yang positif berpengaruh positif terhadap keterlibatan, dan komitmen siswa terhadap sekolah. Keterlibatan, 
kelekatan dan komitmen siswa terhadap aktivitas sekolah dan perkembangan siswa yang positif menyebabkan berkurangnya perilaku berisiko, pada akhirnya secara bersama-sama mempengaruhi keterlibatan kognitif siswa (Dharmayana, 2012).

Sejumlah penelitian menguatkan bahwa siswa yang tidak terlibat dalam pembelajaran merupakan salah satu faktor rendahnya kognitif siswa. Peningkatan keterlibatan perilaku siswa dapat berdampak langsung pada peningkatan pencapaian siswa, semakin banyak siswa yang berpartisipasi aktif dalam kegiatan pembelajaran maka siswa akan semakin memahami isi pembelajaran (Gregory et al., 2014).

\section{KESIMPULAN}

Penerapan cooperative learning tipe peer teaching untuk meningkatkan keterlibatan siswa dalam pembelajaran biologi yang dilakukan selama tiga siklus menghasilkan peningkatkan keterlibatan siswa HA dan LA. Peningkatan keterlibatan siswa terjadi pada Behavioral Engagement (BE), Psychological Engagement (PE) dan Cognitive Engagement (CE).

\section{DAFTAR PUSTAKA}

Ary, D., Jacobs, L. C., Sorensen, C., \& Razavieh, A. (2010). Introduction to Research in Education.

Balgopal, M. M., \& Wallace, A. M. (2009). Decisions and Dilemmas: Using Writing to Learn Activities to Increase Ecological Literacy. Journal of Environmental Education, (June 2016). https://doi.org/10.3200/JOEE.40.3.13-26

Dharmayana, W. (2012). Keterlibatan Siswa ( Student Engagement ) sebagai Mediator Kompetensi Emosi dan Prestasi Akademik. Jurnal Psikologi, 39(1), 76-94.

Dixson, M. D. (2015). Measuring Student Engagement in the Online Course: The Online Student Engagement Scale ( OSE ), 19(4).

Edwards, S. (2015). Active Learning in the Middle Grades. Middle School Journa, (May), 26-32.

Furrer, C. J., Skinner, E. A., \& Pitzer, J. R. (2014). The Influence of Teacher and Peer Relationships on Students Classroo Engagement and Everyday Motivational Resilience, 113(1), 101-123.

Gregory, A., Allen, J., \& Mikami, A. (2014). Effects of A Professional Development Program on Behavioral Engagement of Student in Middle and High School. Psychology in the Schools, 51(2). https://doi.org/10.1002/pits

Grier-reed, T., Appleton, J., Rodriguez, M., Ganuza, Z., \& Reschly, A. L. (2012). Exploring the Student Engagement Instrument and Career Perceptions with College Students, 2(2), 85-96. https://doi.org/10.5539/jedp.v2n2p85

Hafiz, A., \& Wisdiarman. (2014). Pengaruh Metode Peer Tutoring (Tutor Sebaya) Terhadap Hasil Belajar Ditinjau dari Motivasi Belajar Mahasiswa dalam Mata Kuliah Menggambar Bentuk Pada Jurusan Seni Rupa FBS UNP
Padang. Jurnal Pendidikan Bahasa, Sastra, Dan Seni, $X V, 80-91$.

Herrmann, K. J. (2013). The impact of cooperative learning on student engagement: Results from an intervention, 14(3), 175- 187. https://doi.org/10.1177/1469787413498035

Huda, M. (2013). Cooperative Learning.

Latipah, E. (2010). Strategi Self Regulated Learning dan Prestasi Belajar : Jurnal Psikologi, 37(1).

Mandernach, B. J. (2015). Assessment of Student Engagement in Higher Education: A Synthesis of Literature and Assessment Tools. International Journal of Learning, Teaching and Educational Research, 12(2), 1-14.

Maria, U. (2012). Optimalisasi Hasil Belajar IPA Tentang Sistem Gerak pada Manusia Melalui Metode Diskusi dengan Tehnik Pembelajaran Tutor Sebaya. Dinamika, 3(1).

Overby, K. (2011). Student-Centered Learning. College of DuPage, 9.

Prince, M. (2004). Does Active Learning Work? A Review of the Research. Journal of Engineering Education, (July).

Pusporini, N. (2011). Penerapan Model Pembelajaran Tutor Sebaya pada Mata Pelajaran Sosiologi. Jurnal Komunitas, 3(1), 103-120.

San, S., Putu, R., \& Manik, W. (2013). Pengaruh Model Pembelajaran Kontekstual Berbantuan Tutor Sebaya Terhadap Hasil Belajar Biologi Ditinjau dari Motivasi Belajar. E-Journal Program Pascasarjana Universitas Pendidikan Ganesha, 3(3).

Schmidt, K. (2002). Classroom Action Research: A Case Study Assessing Students Perceptions and Learning Outcomes of Classroom Teaching Versus On-line Teaching. Journal of Industrial Teacher Education, 40(1).

Smit, K., Brabander, C. J. De, \& Martens, R. L. (2014). Student-centred and teacher-centred learning environment in pre-vocational secondary education: Psychological needs, and motivation. Scandinavian Journal of Educational Research, 58(6), 695-712.

Usman, R. (2017). Penggunaan Tutor Sebaya dan Aktivitas Siswa untuk Meningkatkan Hasil Belajar Pokok Bahasan Analisis Isi Pidato Siswa Kelas VIII SMP Negeri 2 Tapung. FKIP Unversitas Terbuka UPBJJ-UT Pekanbaru, 5, $16-27$.

Velez, J. J. (2011). Cultivating Change Through Peer Teaching. Journal of Agricultural Education, 52(1), 40-49. https://doi.org/10.5032/jae.2011.01040

Warsono, \& Hariyanto. (2014). Pembelajaran Aktif.

Williams, B., \& Fowler, J. (2014). Can Near-Peer Teaching Improve Academic Performance? International Journal of Higher Education, 3(4), 142-149. https://doi.org/10.5430/ijhe.v3n4p142

Zhao, C., \& Kuh, G. D. (2004). Adding Value: Learning Communities and Student Engagement. Human Sciences Press, 45(2), 115-138. 